\title{
Antibacterial Behavior of Weed Plants from Aseer, Saudi Arabia and Their Possible Mode of Action
}

\author{
Mohamed Hashem ${ }^{1}$, Saad A. Alamri ${ }^{2}$, Ashia A. Shathan ${ }^{3}$, Sulaiman A. Alrumman ${ }^{4}$, \\ Mahmoud F. M. Moustafa ${ }^{5}$ \\ ${ }^{1}$ Biology Department, College of Science, King Khalid University, Abha 61471, Saudi Arabia, \\ Botany and Microbiology Department, Faculty of Science, Assiut University, Assiut 71516, Egypt \\ ${ }^{2,3,4}$ Biology Department, College of Science, King Khalid University, Abha 61471, Saudi Arabia \\ ${ }^{5}$ Biology Department, College of Science, King Khalid University, Abha 61471, Saudi Arabia, \\ Botany Department, Faculty of Science, Qena, South Valley University, Egypt
}

\begin{abstract}
With steadily growing of the microbial resistance against the classical antibiotics, searching new and effective natural antimicrobial agents become crucial. The study introduces new herbal extracts as antibacterial agents against both Gram-positive and Gram-negative bacteria. In vitro antibacterial activity of 15 weed plant species, collected from Aseer region, Saudi Arabia and their effective minimum inhibitory concentrations (MIC) were determined. The possible mode of action of the most effective plant extracts was investigated. Crude extracts of the investigated species were prepared using three organic solvents. Bacillus subtilis and Proteus vulgaris were used as test organisms to evaluate the antibacterial effect of the crude extracts and their (MIC). Examination with scanning electron microscopy of the treated bacteria as well as analysis of the plant extract using GC-MS were performed to explore the possible mode of action. Foeniculum vulgare, Xanthium spinosum, Abutilon pannosum, Solanum incanum, Forsskaolea tenacissima and Brassica deflexa were the most effective plants among the fifteenth tested species. Scan electron micrographs (SEM) revealed a clear morphological malformation in the bacterial shapes. This supports our hypothesis that extracts could alter the bacterial cell membrane permeability causing plasmolysis. GC-MS analysis of plant extracts proved the presence of aliphatic and aromatic compounds, whereas, the number and types of these compounds depended on the type of the organic solvent. The chloroform extracts of Xanthium spinosum, Abutilon pannosum are very promising antibacterial agents against both Gram-positive and Gram-negative bacteria. Further investigation is recommended to scale up and validate the application of the test plant extracts.
\end{abstract}

Keywords: Antibacterial, Weed plants, SEM, GC-MS, Saudi Arabia, Xanthium spinosum, Abutilon pannosum

\section{Introduction}

Antibiotics have been critical in treatment of the microbial diseases during the past decades [1,2]. Because of developing new microbial mutants, some organisms become more resistant to the chemical antibiotics, consequently, many chemicals become non-effective to fight these microbes. Therefore, seeking new natural antimicrobial agents is becoming more urgent than any time before. Nowadays, natural products have been recognized as an important tool in the drug discovery process. In addition, small molecules from natural products are still major sources of innovative therapeutic agents for various conditions, including infectious diseases [3]. Herbal flora play a critical role in control of microbial diseases [4]. Plants that have antimicrobial activity are known to be numerous, but research in the area of antimicrobial activity of medicinal and weed plant is still to be needed [5]. The search for biologically active compounds requires a bioassay procedure to detect a certain type of biological activity in the corresponding crude extracts [6]. This type of research was given a great interest to investigate medicinal properties of more number and species of the wild plants in all over the world [7].

In the Kingdom of Saudi Arabia, about 2100 plant species were recorded, which has about 35 endemic plant species. Distributions of the plants are concentrated in the dry areas of the Kingdom, mainly in low-lying areas, where water collects after rain. Some types of plant families have been tested and proven effective medical [5]. Climate of Saudi Arabia varies from region to another for different terrain, which is located under the influence of high air orbital, and generally, climate is continental hot summer, cold in winter and rainfall winter. Moderate climate on the southwestern highlands that have rainfall seasonal in summer heavier than other regions, and the humidity relative rises on the coast, led to the diversity of vegetation [8]. The southwestern part of Saudi Arabia (Aseer) has a unique environmental climate and latitude, which accommodate growing of specific groups of plants that could have their special phytochemical characteristics. Until now, information about the chemical characteristics and antimicrobial properties of Aseer flora is not fully achieved. From this point of view, this study aimed to investigate the antibacterial properties and chemical characteristics of some weed plants grown in this specific area.

\section{Materials and methods}

\subsection{Plant species}

Fifteen plant species were obtained from different localities of Aseer region (during the period of July-September, 2013). Fresh plant samples were collected and put in sterilized polyethylene bags and transferred to the laboratory. The plants were identified on the species level by a plant taxonomist with aiding of taxonomical plant guides [9]. 


\section{International Journal of Science and Research (IJSR) \\ ISSN (Online): 2319-7064}

Index Copernicus Value (2013): 6.14 | Impact Factor (2014): 5.611

\subsection{Preparation of the crude extract}

Enough fresh quantity of each plant species was washed thoroughly several times with distilled water, and dried in shad and open air at room temperature for 2 weeks. Then, the plant material was ground in a hammer mill to be fine powder. Fifty grams of each plant was put in 500-mL flask, and $100 \mathrm{~mL}$ of a desired solvent (chloroform, ethanol or hexane) was added. The flask was shaking gently for three days. The produced extract was filtered through filter paper, dried in vacuum at $40{ }^{\circ} \mathrm{C}$, and the obtained dry material was weighed. The crude extract of each plant species was made by dissolving a known weight in definite volume of dimethyl sulfoxide (DMSO) to give known concentration. The produced extract was sterilized by passing through a $0.45-\mu \mathrm{m}$ cellulose acetate membrane. All extracts were maintained under cooling $\left(-4^{\circ} \mathrm{C}\right)$ until use.

\subsection{Test microorganisms}

Bacillus subtilus and Proteus vulgaris were used as test microorganisms and representative of Gram positive and Gram negative bacteria, respectively. They were obtained from microbiology department, faculty of medicine, King Khalid University. The nutrient agar medium (beef extract, $10 \mathrm{~g}$; peptone, $10 \mathrm{~g}$; $\mathrm{NaCl}, 5 \mathrm{~g}$; agar, $15 \mathrm{~g}$ and distilled water $1 \mathrm{~L}$ ) was used for growing and preservation of the bacterial species.

\subsection{Screening of antimicrobial activity of the plant extract}

Antibacterial activity of the plant crude extracts was carried out using disc-diffusion method as described by Murray et al. [10] with minor modification. The loaded filter paper discs were placed on the surface of the nutrient agar medium $(15 \mathrm{~mL} /$ plate $)$ inoculated with the desired bacterial species. Negative control was prepared using respective solvent. Standard antibacterial Remox (10 $\mu \mathrm{g} /$ disc) was used as positive control. The plates were incubated for $24-48 \mathrm{~h}$ at 37 ${ }^{\circ} \mathrm{C}$, and the inhibition zone was recorded. The test was repeated twice in three replicates

\subsection{Minimum inhibitory concentration (MIC)}

The MIC was determined according to Kariba et al [11]. Briefly; filter paper discs (diameter, $5 \mathrm{~mm}$ ) were impregnated with $60 \mu \mathrm{L}$ of the reconstituted samples at concentrations of $(25-150 \mathrm{mg} / \mathrm{mL})$. The discs were transferred aseptically into Petri plates containing nutrient agar medium that were inoculated previously with the test microbe. The MIC was considered as the lowest concentration that produced a visible zone of inhibition. For each test, triplicates were used. The plates were incubated at $37{ }^{\circ} \mathrm{C}$ for $24-48 \mathrm{~h}$.

\subsection{Studying the mode of action of the most active extract}

\subsubsection{Scanning electron microscopy}

Cultures of bacteria, treated with different concentration of the most active compounds (based on screening test), was used for all scanning electron microscopic (SEM) observations. Segments of $5 \times 10 \mathrm{~mm}$ was cut from growing cultures and promptly placed in vials containing $3 \%$ glutaraldehyde in $0.05 \mathrm{M}$ phosphate buffer ( $\mathrm{pH} \mathrm{6.8)}$ at $4{ }^{\circ} \mathrm{C}$. Samples were kept in this solution for $48 \mathrm{~h}$ for fixation and then washed with distilled water three times for $20 \mathrm{~min}$. The sample was dehydrated in an ethanol series $(30 \%, 50 \%$, $70 \%$, and $95 \%$ ), for $20 \mathrm{~min}$ in each alcohol dilution and finally with absolute ethanol for $45 \mathrm{~min}$. Samples were at critical point dried in liquid carbon dioxide. Following drying, the prepared samples were mounted on standard SEM stubs using double-stick adhesive tabs and coated with gold-palladium electroplating $(60 \mathrm{~s}, 1.8 \mathrm{~mA}, 2.4 \mathrm{kV})$ in a Polaron SEM Coating System sputter coater. The samples were viewed in scanning electron microscope, and photographed.

\subsubsection{GC-MS analysis of the plant extracts}

To determine the chemical composition of the most active plant extracts, gas chromatography-mass spectrometry (GCMS) was used. One $\mu \mathrm{L}$ of solvent containing the plant extract was injected into the GC-MS (6890 N/5975B). The HP-5MS column was $30 \mathrm{~m}$ in length, $0.25 \mathrm{~mm}$ i.d., and 0.25 $\mathrm{mm}$ in thickness. The carrier gas was helium with average velocity $36 \mathrm{~cm} \mathrm{sec}^{-1}$, and flow $1 \mathrm{~mL} \mathrm{~min}^{-1}$. The operating condition of $\mathrm{GC}$ oven temperature was maintained as follows, initial temperature $40{ }^{\circ} \mathrm{C}$ for $9 \mathrm{~min}, 150{ }^{\circ} \mathrm{C}$ for 8 $\min$, at $15{ }^{\circ} \mathrm{C} \min ^{-1}$ up to final temperature $310{ }^{\circ} \mathrm{C}$ with isotherm for $3 \mathrm{~min}$ at $25^{\circ} \mathrm{C} \mathrm{min}{ }^{-1}$. The injector and detector temperatures were set at 250 and $280{ }^{\circ} \mathrm{C}$, respectively, according to the standard method 8270 EPA [11]. Identification of the components of the prepared extract was assigned by comparison of their retention indices, relative to a series of n-alkane indices on the capillary column and GCMS spectra from the Wiley 6.0 MS data.

\section{Results}

The results of screening test showed that all crude extracts of the fifteen plant species were able to inhibit both $B$. subtilis and $P$. vulgaris, but in various measures. The inhibitory effect was mainly correlated with the plant species and the type of solvent. Chloroform was the best solvent, which exhibited the widest zone of inhibition against both organisms. The most effective crude extract was that obtained from Xanthium spinosum producing inhibition zone $4.20 \mathrm{~cm}$ in case of B. subtilis and $3.63 \mathrm{~cm}$ in case of $P$. vulgaris. The other solvents inhibited the bacteria, but in lower extent. When hexane was used as a solvent, the inhibition zone was $3.40-3.43 \mathrm{~cm}$, however inhibition zone that produced in case of ethanol was $2.72-3.10 \mathrm{~cm}$. The second most effective plant was Abutilon pannosum. Chloroform extract of this plant produced inhibition zone $4.16 \mathrm{~cm}$ against $B$. subtilis and $3.93 \mathrm{~cm}$ and against $P$. vulgaris. However, inhibition zone did not exceed $3.06 \mathrm{~cm}$ when either hexane or ethanol was used as an extraction solvent. Solanum incanum, Foeniculum vulgare and Sisymbrium erysimoides showed good suppressive effect against the two bacteria in the three solvents, however, chloroform was the best one (Table 1). Euphorbia cactus, Amaranthus hybridus, Argemone ochroleuca, Micromeria biflora, Verbesina encelioides and Fagonia arabica moderately inhibited the two organisms. When the chloroform was the extraction solvent, the inhibition zone ranged from $0.73 \mathrm{~cm}$ and $3.40 \mathrm{~cm}$ in case of B. subtilis, and

\section{Volume 4 Issue 11, November 2015}




\section{International Journal of Science and Research (IJSR) \\ ISSN (Online): 2319-7064 \\ Index Copernicus Value (2013): 6.14 | Impact Factor (2014): 5.611}

from $0.96 \mathrm{~cm}$ and $1.30 \mathrm{~cm}$ in case of $P$. vulgaris. The other 4 plants; Withania somnifera, Euphorbia triaculeata, Astragalus collenettiae and Artemisia monosperma showed a weak antibacterial effect against the tested bacteria. The inhibitory effect of chloroform extract of these plants did not exceed $1.0 \mathrm{~cm}$, however the inhibitory effect of the other two solvents noticeably lower than chloroform. Remox 250 $\mathrm{mg} / \mathrm{mL}$ was used as a standard antibacterial drug. The average diameter of inhibition zone resulted by this drug was $4.60 \mathrm{~cm}$ in diameter against Bacillus subtilis and 4.50 $\mathrm{cm}$ against Proteus vulgaris.

The minimum inhibitory concentration (MIC) of the most effective plants was determined based on the preliminary screening test. The results indicated that the lowest MIC was detected in case of Xanthium spinosum $(0.113 \mathrm{mg} / \mathrm{mL})$ when it was extracted in

Table 1: Antibacterial activity of crud extract of the tested plants against different Gram-positive and gram-negative bacteria (inhibition zone in $\mathrm{cm}$ )

\begin{tabular}{|c|c|c|c|}
\hline Plant species & Solvent & Bacillus subtilis & Proteus vulgaris \\
\hline \multirow{3}{*}{ Xanthium spinosum } & Chloroform & $4.2 \pm 1.6$ & $3.63 \pm 1.3$ \\
\hline & Hexane & $3.43 \pm 1.3$ & $3.4 \pm 1.2$ \\
\hline & Ethanol & $3.1 \pm 1.1$ & $2.73 \pm 1.0$ \\
\hline \multirow{3}{*}{ Abutilon pannosum } & Chloroform & $4.16 \pm 1.8$ & $3.93 \pm 1.0$ \\
\hline & Hexane & $2.43 \pm 0.7$ & $3.06 \pm 1.0$ \\
\hline & Ethanol & $2.86 \pm 0.3$ & $2.66 \pm 0.6$ \\
\hline \multirow{3}{*}{ Solanum incanum } & Chloroform & $3.76 \pm 1.6$ & $3.3 \pm 1.2$ \\
\hline & Hexane & $3.1 \pm 1.0$ & $2.16 \pm 0.0$ \\
\hline & Ethanol & $2.56 \pm 0$ & $2.4 \pm 0.3$ \\
\hline \multirow{3}{*}{ Foeniculum vulgare } & Chloroform & $2.5 \pm 1.0$ & $2.16 \pm 0.6$ \\
\hline & Hexane & $1.53 \pm 0.1$ & $2.16 \pm 0.6$ \\
\hline & Ethanol & $1.16 \pm 0.0$ & $1.46 \pm 0.0$ \\
\hline \multirow{3}{*}{ Sisymbrium erysimoides } & Chloroform & $3.03 \pm 0.6$ & $2.86 \pm 1.1$ \\
\hline & Hexane & $2.03 \pm 0.2$ & $1.9 \pm 0.5$ \\
\hline & Ethanol & $2.43 \pm 0.3$ & $0.73 \pm 0.1$ \\
\hline \multirow{3}{*}{ Euphorbia cactus } & Chloroform & $0.83 \pm 0.2$ & $0.96 \pm 0.1$ \\
\hline & Hexane & $1.43 \pm 1.0$ & $1.2 \pm 0.0$ \\
\hline & Ethanol & $1.13 \pm 0.8$ & $1.23 \pm 0$ \\
\hline \multirow{3}{*}{ Amaranthus hybridus } & Chloroform & $1.1 \pm 1.0$ & $1.0 \pm 1.0$ \\
\hline & Hexane & $0.93 \pm 0.2$ & $0.56 \pm 0.1$ \\
\hline & Ethanol & $0.63 \pm 0.1$ & $1.13 \pm 1.0$ \\
\hline \multirow{3}{*}{ Argemone ochroleuca } & Hexane & $0.9 \pm 0.1$ & $1.03 \pm 1.0$ \\
\hline & Ethanol & $1.23 \pm 1.0$ & $0.56 \pm 0.0$ \\
\hline & Chloroform & $0.73 \pm 0.2$ & $1.93 \pm 1.1$ \\
\hline \multirow{3}{*}{ Micromeria biflora } & Chloroform & $0.96 \pm 0.2$ & $1.06 \pm 1.0$ \\
\hline & Hexane & $1.0 \pm 1.0$ & $0.7 \pm 0.0$ \\
\hline & Ethanol & $0.83 \pm 0.2$ & $0.9 \pm 0.2$ \\
\hline \multirow{3}{*}{ Verbesina encelioides } & Chloroform & $3.4 \pm 1.2$ & $1.33 \pm 0.4$ \\
\hline & Hexane & $0.83 \pm 0.2$ & $0.9 \pm 0.0$ \\
\hline & Ethanol & $0.83 \pm 0.2$ & $0.83 \pm 0.2$ \\
\hline \multirow{3}{*}{ Fagonia arabica } & Chloroform & $1.13 \pm 0.9$ & $1.4 \pm 0.7$ \\
\hline & Hexane & $1.36 \pm 0.6$ & $0.93 \pm 0.2$ \\
\hline & Ethanol & $0.8 \pm 0.0$ & 0.0 \\
\hline \multirow{3}{*}{ Withania somnifera } & Chloroform & $0.76 \pm 0.0$ & $1.0 \pm 1.0$ \\
\hline & Hexane & $0.83 \pm 0.2$ & $0.6 \pm 0.0$ \\
\hline & Ethanol & $1.0 \pm 1.0$ & $0.7 \pm 0.0$ \\
\hline \multirow{3}{*}{ Euphorbia triaculeata } & Chloroform & $0.7 \pm 0.4$ & $0.86 \pm 0.3$ \\
\hline & Hexane & $0.8 \pm 1.2$ & $0.8 \pm 0.0$ \\
\hline & Ethanol & $0.73 \pm 0.1$ & $0.83 \pm 0.3$ \\
\hline \multirow{3}{*}{ Astragalus collenettiae } & Chloroform & $0.73 \pm 0.2$ & $0.56 \pm 1.1$ \\
\hline & Hexane & 0.0 & $0.73 \pm 0.0$ \\
\hline & Ethanol & 0.0 & $0.9 \pm 0.2$ \\
\hline \multirow{3}{*}{ Artemisia monosperma } & Chloroform & $0.7 \pm 0.0$ & $0.63 \pm 0.1$ \\
\hline & Hexane & $0.63 \pm 0.1$ & $0.4 \pm 0.0$ \\
\hline & Ethanol & $0.6 \pm 0.0$ & 0.0 \\
\hline Remox & - & $4.6 \pm 0.02$ & $4.5 \pm 0.01$ \\
\hline
\end{tabular}

chloroform against $B$. subtilis and $0.173 \mathrm{mg} / \mathrm{mL}$ against $P$. vulgaris (Table 2). However, the lowest effective dose of Abutilon panosum was $0.117 \mathrm{mg} / \mathrm{mL}$ against $B$. subtilis and $0.195 \mathrm{mg} / \mathrm{mL}$ against
$P$. vulgaris, when the chloroform was the extractive solvent. The MIC of the other three plants, Solanum incanum, Foeniculum vulgare and Sisymbrium erysimoides was higher than the two above-mentioned plants. The effective MIC 


\section{International Journal of Science and Research (IJSR) ISSN (Online): 2319-7064 \\ Index Copernicus Value (2013): 6.14 | Impact Factor (2014): 5.611}

ranged between $0.211 \mathrm{mg} / \mathrm{mL}$ and $0.812 \mathrm{mg} / \mathrm{mL}$ against $B$. subtilis and $0.212-0.963 \mathrm{mg} / \mathrm{mL}$ against $P$. vulgaris

Table 2: Minimum inhibitory concentration (MIC) of crude extract of 5 effective plant against Bacillus subtilis and Proteus vulgaris (concentration in $\mathrm{mg} / \mathrm{mL}$ ).

\begin{tabular}{|l|c|c|c|}
\hline \multirow{2}{*}{ Plant species } & Solvent & $\begin{array}{c}\text { Bacillus } \\
\text { subtilis }\end{array}$ & $\begin{array}{c}\text { Proteus } \\
\text { vulgaris }\end{array}$ \\
\hline \multirow{4}{*}{ Xanthium spinosum } & Chloroform & 0.113 & 0.173 \\
\cline { 2 - 4 } & Hexane & 0.229 & 0.193 \\
\cline { 2 - 4 } & Ethanol & 0.187 & 0.267 \\
\hline \multirow{3}{*}{ Solanum incanum } & Chloroform & 0.117 & 0.195 \\
\cline { 2 - 4 } & Hexane & 0.245 & 0.237 \\
\cline { 2 - 4 } & Ethanol & 0.201 & 0.266 \\
\hline \multirow{3}{*}{ Sisymbrium erysimoides } & Chloroform & 0.211 & 0.234 \\
\cline { 2 - 4 } & Hexane & 0.302 & 0.665 \\
\cline { 2 - 4 } & Ethanol & 0.215 & 0.301 \\
\hline & Chloroform & 0.453 & 0.531 \\
\cline { 2 - 4 } & Hexane & 0.812 & 0.963 \\
\cline { 2 - 4 } & Ethanol & 0.665 & 0.665 \\
\cline { 2 - 4 } & Chloroform & 0.247 & 0.247 \\
\cline { 2 - 4 } & Hexane & 0.265 & 0.212 \\
\hline & Ethanol & 0.271 & 0.223 \\
\hline
\end{tabular}

To explore how the crude extract of the tested plants could inhibit the bacterial growth or kill them, we examined the treated bacterial species with SEM. The results showed that the untreated cells of Bacillus subtilis (Fig. 1 A and B) are regular rods having smooth surface and definite shape, and they did not show any malformation. However, the shape of the treated cells with the crude extract of Xanthium spinosum showed clear visible changes $(\mathrm{C}-\mathrm{F})$. The treated cells exposed shrinking and plasmolysis. The majority of the bacterial cells had concave surfaces and extracellular matrix. Figure 2 shows the scanning electron micrographs of Proteus vulgaris that was treated with crude extract $(0.364$ $\mathrm{mg} / \mathrm{mL}$ ) of Abutilon pannosum against the untreated cells (as control). The treated cells show a clear morphological malformation that makes them with undefined shape. Their appearance approximately oval rather than rode shape, in addition to the adherence of many cells (C-F). However, the untreated cells kept their rode shape and individual characteristic (A and $\mathrm{B}$ ).

The crude extracts of the most effective plants, Xanthium spinosum and Abutilon pannosum that suppressed the tested organisms, were analyzed using GC-MS equipment to explore their fine chemical composition that could help in understanding the
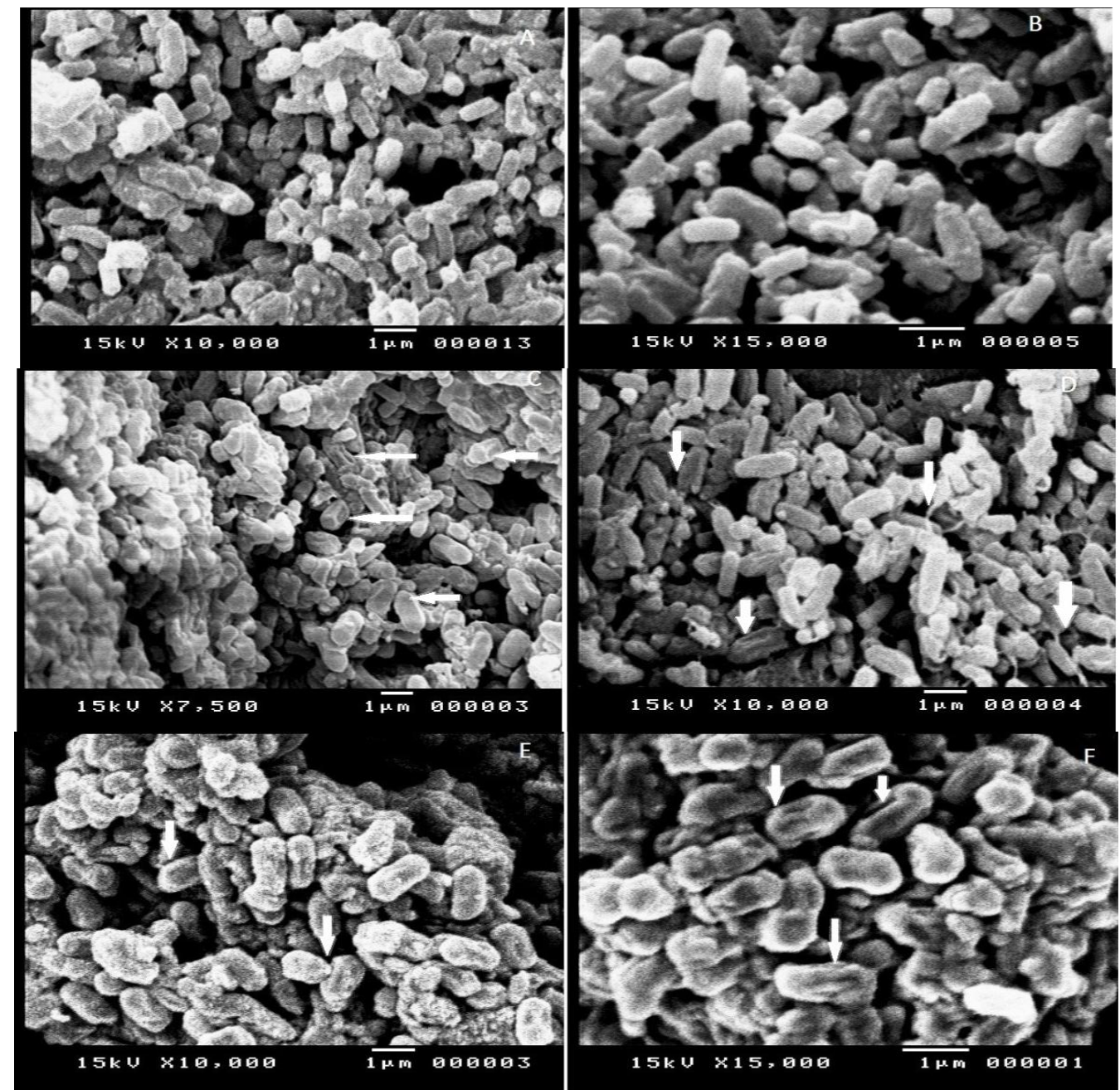

Figure 1: Scanning electron micrographs of Bacillus subtilis treated with cured extract $(0.038 \mathrm{mg} / \mathrm{mL})$ of Xanthium spinosum

The bacterial cell show morphological deformation as a result of treatment with the extract including shrinking and plasmolysis where the arrows point $(\mathrm{C}$ and $\mathrm{D})$. High magnification clearly shows that the cell do not maintain the regular rod shape and smooth surface (E and F) comparing with the untreated cells (A and B).

\section{Volume 4 Issue 11, November 2015}




\section{International Journal of Science and Research (IJSR) ISSN (Online): 2319-7064 \\ Index Copernicus Value (2013): 6.14 | Impact Factor (2014): 5.611}

mode of action of these plant extracts against the microorganisms. Result of GC-MS analysis of the plant extracts led to identification of 30 chemical compounds (Table 3 and 4). The chemical compounds included aliphatic and aromatic components like alcohols and alcohol derivatives, carboxylic acids, ketones, aldehydes, esters, sulfur compounds and amino compounds. Analysis of the crude extract of Xanthium spinosum revealed the presence of 21 different compounds. In chloroform extract, 15 compounds were identified. The main components in this extract were; dimethyl sulfone (21.538\%), 6-fluoro-2trifluoromethylbenzoic acid, 3-fluorophenyl ester (17.102\%) and dimethyl sulfide (11.984\%). The other compounds were detected in percentage $1.639 \%-7.790 \%$. However, in both hexanic and ethanolic extract of this plant, 5 compound were detected. Dimethyl sulfoxide $(16.741 \%)$ and dimethyl sulfone $(76.086 \%)$ were the dominant compounds in the hexanic extract. In the ethanolic extract, 2-Hexaneone, 3,3dimethyl and
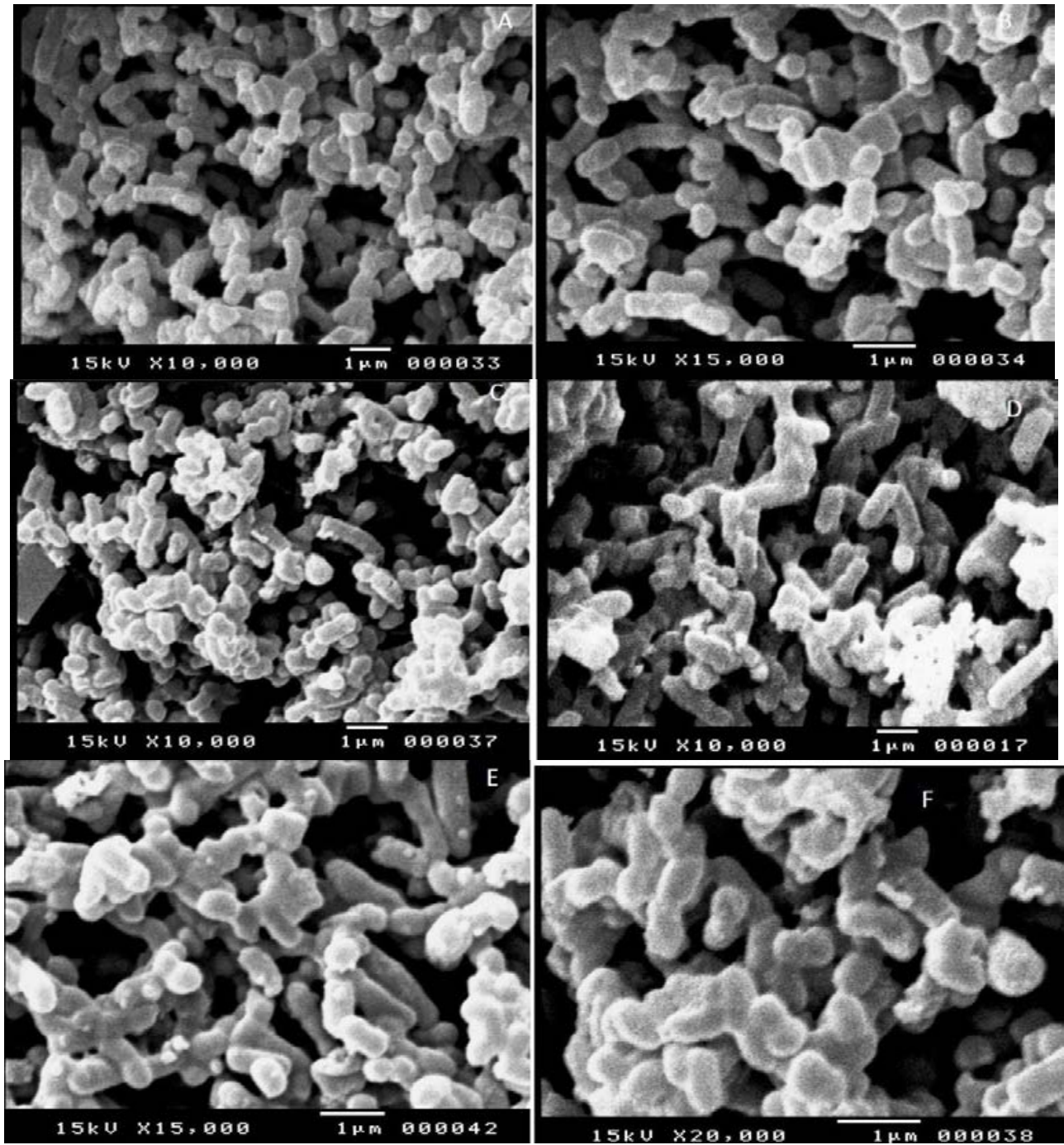

Figure 2. Scanning electron micrographs of Proteus vulgaris treated with crude extract $(0.364 \mathrm{mg} / \mathrm{mL})$ of Abutilon pannosum. The bacterial cells show a clear morphological change (C-F) comparing with the untreated cells (A and B).

ethanone, 1-(3-ethyloxiranyl) were detected as the main components and their percentage was (50.091\%) and $33.855 \%$, respectively. Analysis of the crude extract of Abutilon pannosum approved the presence of 14 different chemical compounds. In each extract, 5 completely different compounds were obtained. In chloroform extract, methane sulfonylacetic acid $(55.696 \%)$ was detected as the main component followed by dimethyl sulfoxide (16.014\%). In hexane extract, 2-Hexaneone, 3,3-dimethyl (52.623\%) and ethanone, 1-(3-ethyloxiranyl) $(35.827 \%)$ were recovered as the fundamental compounds. However, Isooctane (ethenyloxy) (37.917), dimethyl sulfone (20.348\%) and phthalic acid, cyclobutyl ethyl ester $(18.895 \%)$ were the prevalent components.

\section{Discussion}

Our results approved the efficacy of the crude extract of the tested plants against both $B$. subtilis and $P$. vulgaris in convergent level. However, the chloroform extract of Xanthium spinosum and Abutilon pannosum was the most effective one 


\section{International Journal of Science and Research (IJSR) \\ ISSN (Online): 2319-7064}

Index Copernicus Value (2013): 6.14 | Impact Factor (2014): 5.611

Table 3: GC-MS analysis of crude extract of Xanthium spinosum

\begin{tabular}{|c|c|c|c|c|c|c|}
\hline \multirow[b]{2}{*}{ Compound name } & \multicolumn{2}{|c|}{ Chloroform } & \multicolumn{2}{|l|}{ Hexane } & \multicolumn{2}{|c|}{ Ethanol } \\
\hline & $\begin{array}{l}\text { R.T } \\
(\mathrm{min})\end{array}$ & $\begin{array}{l}\text { Percent } \\
(\%)\end{array}$ & $\begin{array}{l}\text { R.T } \\
(\mathrm{min})\end{array}$ & $\begin{array}{l}\text { Percent } \\
(\%)\end{array}$ & $\begin{array}{l}\text { R.T } \\
\text { min) }\end{array}$ & $\begin{array}{l}\text { Percent } \\
(\%)\end{array}$ \\
\hline 1-Pentanol, 2,2-dimethyl & - & - & - & - & 8.14 & 4.14 \\
\hline 2,3-Dimethyloxirane-2-carboxylic acid, methyl ester & - & - & 8.17 & 0.81 & - & - \\
\hline 2-Butanone, 3-hydroxy & - & - & 8.58 & 3.13 & - & - \\
\hline 2-Hexanone, 3,3-dimethyl & - & - & - & - & 6.65 & 50.09 \\
\hline 3-Hexanol & 8.16 & 4.86 & - & - & - & - \\
\hline 3-Hexanone & 16.31 & 3.18 & - & - & - & - \\
\hline 3-Hexen-2-one & - & - & - & - & 9.14 & 7.50 \\
\hline 6-Fluoro-2-trifluoromethylbenzoic acid, 3-fluorophenyl ester & - & 17.10 & - & - & - & - \\
\hline Borane, diethyl (decyloxy) & 41.86 & 5.96 & - & - & - & - \\
\hline Dimethyl sulfide & 6.09 & 11.98 & - & - & - & - \\
\hline Dimethyl sulfone & 7.07 & 21.54 & 7.07 & 76.09 & - & - \\
\hline Dimethyl sulfoxide & - & - & 6.08 & 16.74 & - & - \\
\hline Ethanone, 1-(3-ethyloxiranyl) & - & - & - & - & 7.30 & 33.86 \\
\hline Ethylbenzene & 6.30 & 5.95 & - & - & - & - \\
\hline Ethylenimine & 7.31 & 1.64 & - & - & - & - \\
\hline Hexane, 2,4,4-trimethyl & 30.96 & 2.84 & - & - & - & - \\
\hline Hexane, 3,3-diethyl & 13.65 & 7.79 & - & - & - & - \\
\hline Hydroperoxide, 1-methylpentyl & - & - & - & - & 8.54 & 4.41 \\
\hline Isopropyl lactate & 8.57 & 5.98 & - & - & - & - \\
\hline Nonane, 1-iodo & 27.88 & 7.45 & - & - & - & - \\
\hline Phthalic acid, 4-bromophenyl ethyl ester & 48.22 & 3.73 & 48.25 & 3.35 & - & - \\
\hline
\end{tabular}

against the microorganisms. This finding confirms the wide spectrum antibacterial activity of these extract, whereas they suppressed both Gram-negative

Table 4: GC-MS analysis of crude extract of Abutilon pannosum

\begin{tabular}{|c|c|c|c|c|c|c|}
\hline \multirow{2}{*}{ Compound name } & \multicolumn{2}{|c|}{ Chloroform } & \multicolumn{2}{|c|}{ Hexane } & \multicolumn{2}{c|}{ Ethanol } \\
\cline { 2 - 7 } & R.T (min) & Percent (\%) & R.T (min) & Percent (\%) & R.T (min) & Percent (\%) \\
\hline 2-Heptene, 5-methyl & 8.62 & 4.07 & - & - & - & - \\
\hline 2-Hexanone, 3,3-dimethyl & - & - & 6.66 & 52.62 & - & - \\
\hline 3-Hexan-2-one & - & - & 9.15 & 7.79 & - & - \\
\hline 3-Hexanol & 8.15 & 10.86 & - & - & - & - \\
\hline Benzene, 1,3-dimethyl & - & - & - & - & 6.28 & 8.1 \\
\hline Butane, 2,2-dimethyl & - & - & - & - & 20.92 & 14.74 \\
\hline Dimethyl sulfone & - & - & - & - & 7.03 & 20.35 \\
\hline Dimethyl Sulfoxide & 6.08 & 16.01 & - & - & - & - \\
\hline Ethanone, 1-(3-ethyloxiranyl) & - & - & 7.31 & 35.83 & - & - \\
\hline Isooctane (ethenyloxy) & - & - & - & - & 6.1 & 37.92 \\
\hline Isopropyl lactate & 8.55 & 13.37 & - & - & - & - \\
\hline Methane sulfonylacetic acid & 7.05 & 55.7 & - & - & - & - \\
\hline Pental, 2,2-dimethyl & - & - & 8.14 & 3.76 & - & - \\
\hline Phthalic acid, cyclobutyl ethyl ester & - & - & - & - & 48.17 & \\
\hline
\end{tabular}

and Gram-positive bacteria. These results are supported by many findings of other researchers, who mentioned the efficacy of plant extracts in suppression of bacteria [2,1316]. Results showed that the Gram-positive bacterium $B$. subtilis was rather sensitive to the tested extracts than the Gram-negative $P$. vulgaris. This result was in full agreement with many authors, who deal with antibacterial effect of plant extracts. In this regard, Eftekhar et al. [17] found the methanol extract of Datura stramonium and D. innoxia had a highest antibacterial activity against Gram +ve bacteria and little or no activity against Gram -ve bacterial species. Murthy et al. [13] found that Premna herbaceae inhibited the growth of all Gram +ve bacteria and three out four Gram -ve bacteria. Hugo and Russell [18] reported that the Gram -ve bacteria and fungi have been shown to be more resistant to antibiotics. Eloff [19] showed that the essential oil from
Capillipendrum factidum displayed high antibacterial activity against Gram +ve bacteria and moderate to Gram ve bacterial strains. The resistance of Gram-ve bacteria than Gram +ve bacteria could be due to the permeability barrier provided by the cell wall or to the membrane accumulation mechanism [20] or related to lipopolysaccharides in their outer membrane $[21,22]$.

The variation in antibacterial effect of different extraction solvents, that we reported here, was approved previously by many researchers. Markouk et al. [23] found that the ethyl acetate and n-butanol extracts of Coprinopsis cinerea exhibited effect against Pseudomonas fluorescens and $P$. savastanoui. Ali et al. [24] found that the ethanolic extract of Pulicaria orientalis and Rumex nervosus were inactive against both of Gram +ve and Gram -ve bacteria. Tomas- 


\section{International Journal of Science and Research (IJSR) \\ ISSN (Online): 2319-7064 \\ Index Copernicus Value (2013): 6.14 | Impact Factor (2014): 5.611}

Barberan et al. [25] found that the ethanol extract of Linum capitatum posses activity against both Gram +ve bacteria $(S$. aureus \& B. subtilis) and Gram -ve bacteria (E. coli). They concluded that the ethanol extract of these plants exhibits the best antimicrobial activity than the other extracts. Zaidi et al. [26] reported that the extract of Zygophyllum fabago was significantly effective against $E$. coli and B. subtilis.

To get a clear image about how could the plant extract supress or kill the target bacteria, the treated bacterial cell were examined by the scanning electron microscopy (SEM). Scan micrographs showed that treated cells of either Gramve or Gram+ve bacteria with the crude extract of Xanthium spinosum and Abutilon pannosum showed severe morphological alterations in the bacterial cell wall. A clear malformation in the microbial shapes support the assumption that the mechanism in which the extract affect the cells is via altering the cell membrane permeability that involve in the plasmolysis of the cells and change their shape. The destruction of cell membrane integrity lead to leakage of the internal content of the microbial cytoplasm leading to kill the microorganisms. This could approve the bactericidal effect of such plant extracts. Selectivity and binding site, the modes of action of biocides depend on the type of bacterial organisms and are mainly related to the structure of the cell wall and outer membrane arrangement. This is likely due to the significant differences in the outer layers of Gram-negative and Gram-positive bacteria. Gramnegative bacteria possess an outer membrane and a unique periplasmic space not found in Gram-positive bacteria [27]. Our observation and hypothesis is strongly supported by many other data obtained by many researchers all over the world $[28,29]$. In agreement with our observation, Bajpai et al. [28] mentioned that morphological alterations in bacterial cells might have occurred due to the effect of Cudrania tricuspidata fruit essential oil (CTEO) on membrane integrity, thereby resulting in the lysis of bacterial cell wall followed by the loss of intracellular dense material on the surface of treated cells. This observation was also confirmed by findings of Ghannoum [30]. Changes in membrane fluidity usually occur due to alterations in membrane lipid composition and are thought to be a compensatory mechanism to counter the lipid disordering effects of the treatment agent [31]. The literature suggests that the active components of plant contents such as essential oils might bind to the cell surface and then penetrate to the target sites possibly the plasma membrane and membrane-bound enzymes, resulting in the disruption of cell wall structure $[32,33]$.

The crude extracts of Xanthium spinosum and Abutilon pannosum as the most effective plants against the two bacteria were analyzed using GC-MS to detect their chemical components that could help in understanding their mode of action against the target microbes. The fundamental observation was the number and structure of the detected compounds were greatly depended on the type of the extraction solution. In the chloroform extract of Xanthium spinosum, 15 chemical compounds were detected, however in either hexane or ethanol extract of this plant, 5 different compounds were detected. Only Dimethyl sulfone and Phthalic acid, 4-bromophenyl ethyl ester were observed in both chloroform and hexane extracts of this plant.
Chloroform, hexane and ethanol extracts of Abutilon pannosum contained completely different compounds (5 compounds for each solvent).

The chloroform extract of Xanthium spinosum contained the highest number of chemical compounds and it was the highest effective against the two bacterial species. Among the most common detected chemicals in the crude extract of the plant species was dimethyl sulfone that is used industrially as a high-temperature solvent for both inorganic and organic substances because of its polarity and thermal stability [34]. Ethylenimine was also detected, which is used to inactivate some viruses and mycoplasma. It was assumed that to modify the nucleic acids and alters proteins in virus preparations, especially at higher $\mathrm{pH}$ values. The modification of the proteins affected viral particle uptake into cells [35]. In addition to the presence of compounds that are used as some strong solvents such as hexanol, hexanone, butanol and pentanol or their derivatives. Some compounds such as phthalic acid, 4-bromophenyl ethyl ester and phthalic acid, cyclobutyl ethyl ester that are used in pesticides' manufacturing. Phenolic compounds were mentioned to play a major role in the antimicrobial effects of some plant extracts $[36,37]$. Our results greatly support the previous results that considered the differences in the composition in the extracted compounds could be correlated with the antimicrobial properties of each extract [38].

Based on our data, we could assume that each compound present in the specific extract could play a specific role in suppression of the microbe like as solving of the lipids in the cell wall, altering of protein integrity in the protoplasm, or through denaturation of the DNA of the microbes. Finally, these actions by all chemical compounds that are working synergistically leads to complete suppression or killing the microbe. This assumption is supported by Piccirillo et al. [38], who reported that the synergistic effect could enhance the antibacterial effect of some natural extracts; the particular combination of different molecules, characteristic of each extract, can make the extracts themselves even more interesting than the single isolated compounds. Gallucci et al. [39] mentioned the efficacy of synergistic action between some terpenes on bacteria. Litman et al. [40] reported about the synergistic effect of linalool and eugenol on some fungi species.

We conclude that crude extracts of Xanthium spinosum and Abutilon pannosum are promising antibacterial agents that could take a part in manufacturing an effective new antibiotic to reduce the resistance phenomenon that are growing against the classical antibiotics. However, further studies to scale up and validate the antibacterial effect of the two plants to include a wide range of bacterial species are recommended.

\section{References}

[1] S. Gibbons, "Plants as a source of bacterial resistance modulators and anti-infective agents", Phytochemistry Review, IV (1), pp 63- 78, 2005.

[2] A. Al-Mariri, S. Mazen, "In vitro antibacterial activity of several plant extracts and oils against some gram-

\section{Volume 4 Issue 11, November 2015}




\section{International Journal of Science and Research (IJSR) \\ ISSN (Online): 2319-7064 \\ Index Copernicus Value (2013): 6.14 | Impact Factor (2014): 5.611}

negative bacteria", Iranian Journal of Medical Sciences, XXVIV (1), pp.36-43, 2014.

[3] K. K. Ivaska, T. A. Hentunen, J. Vääräniemi, H. Ylipahkala, K. Pettersson, H. K. Väänänen, "Release of intact and fragmented osteocalcin molecules from bone matrix during bone resorption in vitro. ", Journal of Biological Chemistry, CCLXXIX (18), pp 1836118369, 2004.

[4] F. János, B. De Baets, "A single-point characterization of epresentable uniforms", Fuzzy Sets and Systems CCII (17), pp 89-99. 2012.

[5] D. Webster, P. Taschereau, R.J. Belland, C. Sand, R.P. Rennie, "Antifungal activity of medicinal plant extracts; preliminary screening studies", Journal of Ethnopharmacology, CXV (1), pp 140-146. 2008.

[6] I. Hinnebourg, H.J. Damien, R. Hiltunen, "Antioxidant activities of extracts from selected culinary herbs and spices", Food Chemistry, XCVII (1), pp 122-129, 2006.

[7] C. Oswaldo, T.A. Mokoka, L.J. Mcgaw, J.N. Eloff, "Antifungal efficacy of ten selected South African plant species against Cryptococcus neoformans", Pharmaceutical Biology, IIL (4), pp 397-404, 2010.

[8] J. Madzimure, E. T. Nyahangare, H. Hamudikuwanda, T. Hove, S. R. Belmain, P. C. Stevenson, B.M. Mvumi, "Efficacy of Strychnos spinosa (Lam.) and Solanum incanum L. aqueous fruit extracts against cattle ticks", Tropical Animal Health and Production, VL (6), pp 1341-1347, 2013.

[9] S. Collenette, Wildflowers of Saudi Arabia. Nationnal Commission for Wildlife Conservation and Development (NCWCD), Kingdom of Saudi Arabia, 1999.

[10] P. R. Murray, E. J. Baroon, M. A. Pfaller F. C. Tenover, R. H. Yolke, Manual of Clinical Microbiology", $6^{\text {th }}$ Edn., American Society for Microbiology, Washington, DC, 1995.

[11] F. Cakir, A. Schmitt, R.R. Bélanger, "The effects of plant extracts of Reynoutria sachalinensis on powdery mildew development and leaf physiology of long English cucumber", Plant Disease, LXXIX (6), pp 577-580, 2004.

[12] R.M. Kariba, G.M. Siboe, S.F. Dossaji, "In vitro antifungal activity of Schizozygia coffaeoides Bail. (Apocynaceae) extracts", Journal of Ethnopharmacology, LXXIV (1), pp 41-44. 2001.

[13] K. Murthy, R. Kondamudi, T. Pullaiah, "High frequency somatic embryogenesis in Ceropegia spiralis Wight. An endemic and endangered medicinal plant", Indian Journal of Biotechnology, IX (4), pp 414 $-418,2010$.

[14] S. Y. Daniyan, M. E. Abalaka, M. Galadima, L. E. Odama, O. S. Olonitola, "Comparative analysis and antimicrobial activity of essential oil constituents of hyptis suaveolens from Nigeria", American Journal of Traditional Medicine \& Pharmaceutical Sciences I(1), pp 8-12, 2013.

[15] T. Indhumathi, S. Mohandass, "Efficacy of ethanolic extract of Solanum incanum fruit extract for its antimicrobial activity", International Journal of Current Microbiology and Applied Sciences, III (6), pp 939-949, 2014.
[16] V. Pankyamma, K. B. Puthanpurakkal, V. Sivam, B. Jaganath, N. R. Chandragiri, K. S. G. Teralandur, "Efficacy of mint (Mentha arvensis) leaf and citrus (Citrus aurantium) peel extracts as natural preservatives for shelf life extension of chill stored Indian mackerel" Journal of Food Science and Technology, LII (10), pp 6278-6289, 2015.

[17] O.A. Eftekhar, J.F. Finnie, J. Van Staden, "Antimicrobial activity and mutagenic effects of twelve traditional medicinal plants used to treat ailments related to the gastro-intestinal tract in South Africa", Journal of South African Botany, LXXV(2), pp 356-362, 2009.

[18] S. B. Hugo, A.D. Rusell, Pharmaceutical Microbiology 3rd Edition. Blackwell Scientific Publication, London pp. 105-125, 1983

[19] J. N. Eloff "A sensitive and quick microplate method to determine the minimal inhibitory concentration of plants extracts for bacteria”, Planta Medica, LXIV (8), 711-713, 1998.

[20] K. Adwan, N. Abo-Hasan, "Gentamicin resistance in clinical strains of Enterobacteriaceae associated with reduced gentamicin uptake", Folia Microbiologica, XLIII (4), 438-440, 1998.

[21] M. Sawer, A. Cgceres, O. Aviles, V. Freire, L.M. Giron, J.G. Pacheco, "Moringa oleifera (Moringaceae), Ethnobotanical Studies in Guatemala", Economic Botany, XLV (4), 522-523, 1997.

[22] F.B. Gao, J.E. Brenman, L.Y. Jan, Y.N. Jan, “Genes regulating dendritic outgrowth, branching, and routing in Drosophila", Genes and Development, XIII (19), 2549-2561, 1999.

[23] M. Markouk, H.B. Lazrek, M. Larhsini, K. Bekkouche, M. Jana, "Preliminary screening of antiprotozoal activity of extracts from Cotula cinerea L.", Therapie, LIV (4), 763-776, 1999.

[24] A. M. A. Rahman, T. Parvez, D.K. Parvin, M. A. Sattar, "Antimicrobial activity of three bioactive compound from the stream bark of Piper chaba Hunter”. Bioscience Research, I (1), 16-20, 2001.

[25] F.A Tomas-Barberan, J.D. Msonthi, N. K. Hostettman, "Antifungal epicuticular methylated flavonoids from three Spanish Helichrysum species", Phytochemistry XXVII (3) pp 753-755, 1988.

[26] M. A. Zaidi, A. Sidney, J.R. Crow, "Cytotxicity of four medicinal plants of Pakistan", Pakistan Journal of Botany, XLIV, (3) pp 395-397, 2012.

[27] J. Dzidic, P. Giordani, G. Brunialti, P. Modenesi, "Applicability of the lichen biodiversity method (LB) in a Mediterranean area (Liguria, NW Italy)", Cryptogam Mycology, XXII (3), pp 193-208, 2008.

[28] V. K. Bajpai, A. Sharma, K-H. Baek, "Antibacterial mode of action of Cudrania tricuspidata fruit essential oil, affecting membrane permeability and surface characteristics of food-borne pathogens", Food Control, XXXII (2), pp 582-590, 2013.

[29] M. Diaz, G. Oboh, E.E. Nwanna, C.A. Elusiyan, "Antioxidant and antimicrobial properties of Telfairia occidentalis (fluted pumpkin) leaf extracts", Journal of Pharmacology and Toxicology, V (8), pp 539-547, 2010.

[30] M. A. Ghannoum, "Studies on the anticandidal mode of action of Allium sativum (Garlic)", Journal of 
General Microbiology, LXXXIV (11), pp 2917-2924, 1988.

[31] J. Sikkema, J. A. M. De Bont, B. Poolman, "Mechanism of membrane toxicity on hydrocarbons", Microbiology Review, LIX (2), pp 201-222, 1995.

[32] S. Y. Zhu, Y. Yang, H. D. Yu, Y. Ying, G. L. Zou, "Chemical composition and antimicrobial activity of the essential oils of Chrysanthemum indicum", Journal Ethnopharmacology, XCVI (1-2), pp 151-158, 2005.

[33] V. K. Bajpai, S. M. Al-Reza, U. K. Choi, J. H. Lee, S. C. Kang, "Chemical composition, antibacterial and antioxidant activities of leaf essential oil and extracts of Metasequioa glyptostroboides Miki ex Hu.", Food and Chemical Toxicology, XLVII (8), pp 1876-1883, 2009.

[34] A. Tox, N. A. David, "The pharmacology of dimethyl sulfoxide," Annual Review of Pharmacology, XII (4), pp 353-374, 1972

[35] Bahnemann, H. G, "Binary ethylenimine as an inactivant for foot-and-mouth disease virus and its application for vaccine production", Archives of Virology, XLVII (1), pp 47-56, 1975.

[36] J.A, Lemos, X.S. Passos, O.F. Fernandes, J.R. Paula, P.H. Ferri, L.K. Souza, A.A. Lemos, M. R. Silva, "Antifungal activity from Ocimum gratissimum L. towards Cryptococcus neoformans", Memorias do Instituto Oswaldo Cruz, C (1), pp 55-58, 2005.

[37] K. Pirbalouti, D. Mares, B. Tosi, F. Poli, E. Andreotti, C. Romagnoli,. Antifungal activity of Tagetus patula extracts on some phytopathogenic fungi, ultrastructural evidence on Pythium ultimum", Microbiological Research, CLIX (3), pp 295-304, 2011.

[38] T. Piccirillo, G. Miliauskas, P.R. Venskutonis, T.A. Beek, "Screening of radical scavengingactivity of some medicinal and aromatic plant extracts", Food Chemistry, LXXXV (2), 231-237, 2013.

[39] I. Gallucci, I. Bhattachajee, A. Ghosh, G. Chandra, "Antimicrobial activity of the essential oil of Cestrum diurnum (L.) (Solanales, Solanaceae)", African Journal of Biotechnology., IV (4), pp 371-374, 2009.

[40] G.W. Litman, N.A. Hawke, J.A. Yoder, "Novel immune-type receptor genes", Immunological Reviews, CLXXXI (6), pp 250-259, 2001. 